\title{
A Rare Cause of Dysphagia
}

\section{Uma Causa Rara de Disfagia}

Andreia RIBEIRO $\square^{1}$, Gonçalo FREIRE ${ }^{2}$

Acta Med Port 2021 Nov;34(11):782-783 - https://doi.org/10.20344/amp.13628

Keywords: Aneurysm, Infected; Aortic Aneurysm, Thoracic; Deglutition Disorders

Palavras-chave: Aneurisma da Aorta Torácica; Aneurisma Infectado; Perturbações de Deglutição

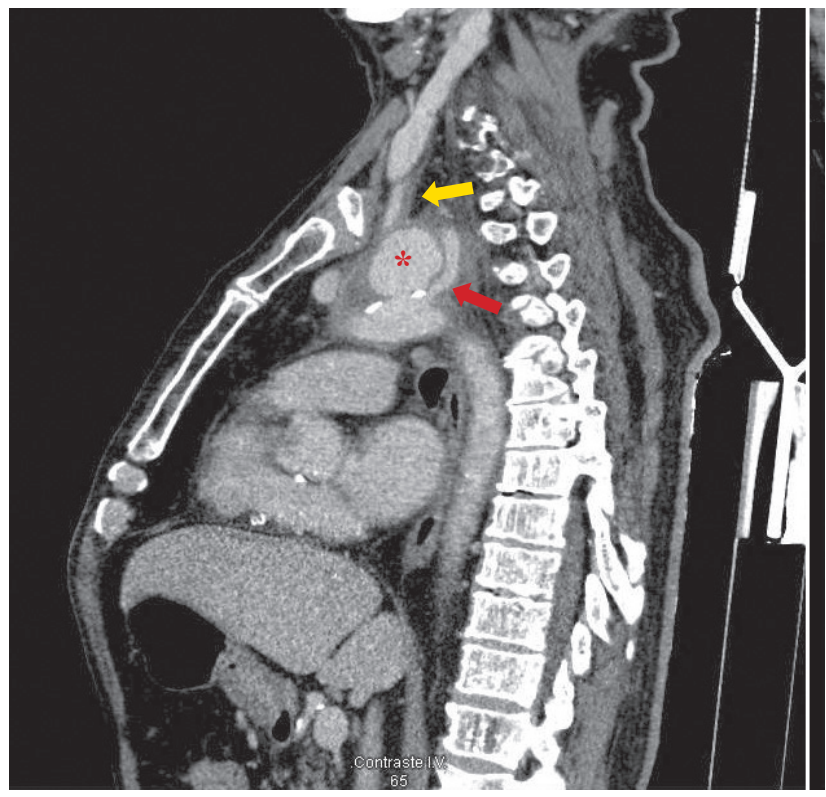

Figure 1 - Contrast-enhanced thoracic CT with sagittal reconstruction, demonstrating a saccular aortic arch aneurysm (asterisk), between the origin of the left carotid artery (yellow arrow) and the left subclavian artery (red arrow). It had a thickened and irregular wall, compatible with an infected aortic aneurysm, with no signs of rupture.

A 77-year-old man presented with a 2-week history of dysphonia and dysphagia, with concomitant anorexia, sporadic fever, and weight loss. Laboratory studies revealed neutrophilic leukocytosis and a high C-reactive protein level, and chest radiography showed left mediastinal widening. Computed tomography was performed and depicted a saccular aortic arch aneurysm, having a thickened and irregular wall, with extension to the left carotid artery (Figs. 1, 2).

A mycotic aortic aneurysm is an aortic aneurysm due to infection, most commonly involving bacteria. ${ }^{1,2}$ It is a rare condition, with an estimated incidence of $0.6 \%$ to $2.0 \%$ of all aortic aneurysms. ${ }^{3}$ They are associated with significant morbidity and mortality and prognosis depends on the presence of rupture or sepsis and the virulence of the microorganism. ${ }^{4}$

This patient underwent carotid-carotid bypass and surgi-

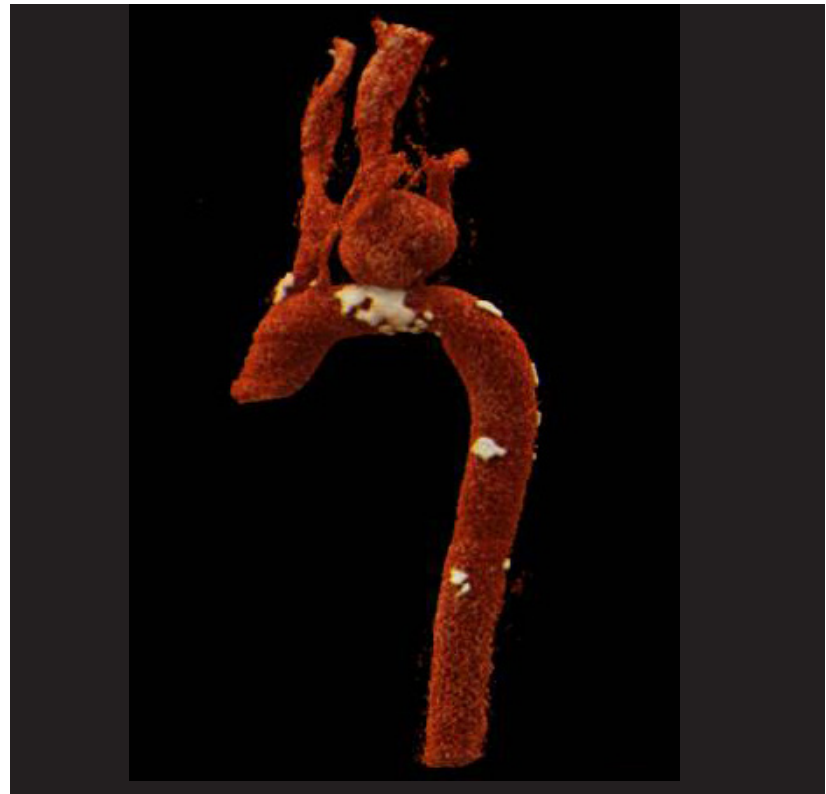

Figure 2 - Three-dimensional CT reconstructions of the mycotic aneurysm were performed to plan surgical treatment

cal repair of the mycotic aneurysm. He completed a 6-week course of metronidazole and vancomycin and his recovery was unremarkable.

\section{AUTHORS CONTRIBUTION:}

AR: Acquisition of data; literature review, draft of the paper.

GF: Image processing; critical review of the paper and of the literature.

\section{PROTECTION OF HUMANS AND ANIMALS}

The authors declare that the procedures were followed according to the regulations established by the Clinical Research and Ethics Committee and to the Helsinki Declaration of the World Medical Association updated in 2013.

\footnotetext{
1. Unidade de Saúde Familiar Descobertas. Agrupamento de Centros de Saúde Lisboa Ocidental e Oeiras. Lisboa. Portugal.

2. Serviço de Radiologia. Hospital Beatriz Ângelo. Loures. Portugal.

$\triangle$ Autor correspondente: Andreia Ribeiro. andreiateles@campus.ul.pt

Recebido: 20 de fevereiro de 2020 - Aceite: 01 de abril de 2020 - First published: 23 de agosto de 2021 - Online issue published: 02 de novembro de 2021 Copyright $\odot$ Ordem dos Médicos 2021
} 


\section{DATA CONFIDENTIALITY}

The authors declare having followed the protocols in use at their working center regarding patients' data publication.

\section{INFORMED CONSENT}

Obtained.

\section{COMPETING INTERESTS}

All authors report no competing interests.

\section{FUNDING SOURCES:}

The authors declare that there were no external sources of study for the performance of this article.

\section{REFERENCES}

1. Lin $\mathrm{CH}$, Hsu RB. Primary infected aortic aneurysms: clinical presentation, pathogen and outcome. Acta Cardiol Sin. $2014 ; 30: 514-21$.

2. Bisdas T, Teebken OE. Mycotic or infected aneurysm? Time to change the term. Eur J Vasc Endovasc Surg. 2011;41:517.

3. Sörelius K, Wanhainen A, Furebring M, Björck M, Gillgren P, Mani K, et al. Nationwide study on the treatment of mycotic abdominal aortic aneurysms comparing open and endovascular repair. Circulation. 2016;134:1828-32.

4. Kim YW. Infected aneurysm: current management. Ann Vasc Dis. 2010;3:7-15 